\title{
Chapter 6 \\ Perceived Fairness and Worker Well-Being \\ in Public, For-Profit and Nonprofit Firms: Evidence from the Italian Social Service Sector
}

\author{
Ermanno Tortia
}

\begin{abstract}
This essay analyzes the links between workers' fairness concerns and job satisfaction in different ownership and organizational forms of the Italian social service sector. Social cooperatives emerge as the organizational form that best sustains the perception of procedural fairness. On the other hand, the public sector shows the most serious weaknesses. A clear difference emerges between the public and the private sector in general, with the former at a disadvantage. Given the very significant role of procedural fairness in influencing job satisfaction, social cooperatives turn out as an innovative and successful organizational form, at least as far as labour relations are concerned, the difficulties in retaining their more educated and skilled workforce notwithstanding.
\end{abstract}

\subsection{Introduction}

The Italian social service sector presents an interesting case of institutional and organizational plurality since it encompasses markedly different ownership and organizational forms. The sector is dominated by nonprofit organizations which, as a whole, represent about $70 \%$ of the total number of organizations. ${ }^{1}$

\footnotetext{
${ }^{1}$ Data are taken from the FIVOL-FEO survey. The 2001 ISTAT Italian Census on Industry and Services recorded 1,401,481 workers employed in the health care and social service sector at the national level. Since a census of social services alone did not exist in Italy at the time the research was performed (1998), one was carried out directly on the basis of administrative sources in the ex-ante selected 15 provinces (out of a total of 107), which were representative of the different social and economic conditions of the country. Two different services were selected for each province and organizations were drawn at random from the census. The sampling procedure seems sound, since the social service sector alone can be estimated to employ about 500,000 workers nationally. Also the distribution of ownership forms in the FIVOL-FEO sample fairly well reflected the national distribution, even though for-profits were over-represented in order to allow meaningful comparisons.
}

\footnotetext{
E. Tortia

Department of Economics, University of Trento and European Institute for Cooperative and Social Enterprise, Via Inama 5, 38100 Trento, Italy
} 
Also with regard to nonprofits, variety is the dominant feature since they are sorted into social cooperatives and traditional nonprofits (associations and foundations), which are partly religious and partly non-religious. Introduced in Italy in 1991 (Law 381/1991), social cooperatives are still a young and growing organizational form and represent an interesting case of institutional hybridization since they pertain to the law on cooperative enterprises but retain many of the features of nonprofit organizations, such as non-distributable and mission-devoted assets with an explicit social aim. They are also allowed to operate as multi-stakeholder organizations controlled by representatives of different patrons, such as volunteers, workers, and customers.

The public sector provides an important, but not dominant, share of social services, while for-profit firms are mainly concentrated in activities requiring relatively high capital intensity (like residential homes). Such an institutional variability is not so common in contemporary market economies since most sectors are dominated either by for-profit firms or by publicly-owned organizations. Various theories have been set forth concerning the reasons why social and welfare services are observed in many countries to embrace a significant share of nonprofit organizations (Weisbrod 1977, 1988; Hansmann 1996; Borzaga 2003). Even nowadays market imperfections in the form of internal and external agency problems continue to provide the basis for an explanation to this evidence. However, a growing number of articles is no longer satisfied with this traditional neo-institutionalist explanation and endeavours to introduce new arguments in a more evolutionary and developmental fashion. More democratic, socially oriented and inclusive organizational forms, often embedded at the local level, would be better suited to engender a high degree of procedural fairness because of the different objectives, financial structure, and less costly incentive mix used to motivate workers (Borzaga and Tortia 2007a, b, 2008). The objectives are no longer defined in terms of maximizing the expected financial value of the organization, but rather in terms of satisfying specific needs that can be private, but also social, and correspond to the production of community interest goods and services. Finally, the incentive mix used to motivate workers takes into account not only self-interested motivation of an economic and monetary type, but also relational, process-related and other relevant motivations (Borzaga and Mittone 1997; Ben-Ner and Putterman 1999; Bacchiega and Borzaga 2001, 2003). This specific organizational setting would, in turn, be particularly suitable to produce services requiring a high content of trust and good relations between users and firms. In this research stream, institutional evolution is a key issue in explaining the ability of different organizational forms to adapt to the surrounding economic environment. New institutional tools, such as mission-oriented multi-stakeholdership correspond to the satisfaction of specific needs.

This study concentrates on the comparative analysis of the determinants of worker well-being, which is indexed by job-satisfaction and loyalty to the organization. Special attention will be given to the role of workers' fairness perceptions in distributive and procedural terms as determinants of well-being. Our analysis may be considered the continuation of a previous work (Tortia 2007) dealing with the overall impact of fairness on worker well-being as compared with wage and effort. The comparative analysis is explored in greater depth by introducing descriptive statistics for all the 
five organizational forms existing in the sector, and by running separate regressions for each organizational form in order to highlight the different composition and weight of the determinants of well-being in different institutional contexts. Furthermore, job satisfaction, described in terms of satisfaction with fourteen different aspects of the job, is sorted into two components, representing the "material" and the "non-material" aspects. Separate regressions will be run for the two components in order to highlight how they are influenced by different features of workers and of the work environment. It will be seen that fairness, mainly of a procedural kind, represents a transversal determinant of well-being, impacting heavily on all the components of satisfaction as well as on loyalty. In this regard, it can be said that the fairness of procedures emerges as an intrinsic workers' need to seek fulfilment in organizations, whatever the ownership and the organizational form. However, different forms clearly appear to sustain markedly different degrees of fairness. Social cooperatives are best able to guarantee a high degree of procedural fairness, while many critical aspects emerge in the public sector. By guaranteeing better relations on the job and fairer procedures, nonprofits in general are able to offset other weaknesses that have to do mainly with weaker monetary and material incentives.

This paper is organized as follows: Sect. 6.2 presents the descriptive analysis of the variables involved focussing predominantly on the comparison between different perceptions of distributive and procedural fairness in the five organizational forms. Section 6.3 introduces the econometric analysis where the factors influencing overall material and non-material job-satisfaction, together with loyalty to the organization, will be introduced and studied. Section 6.4 discusses the main results and conclusions.

\subsection{The Descriptive Analysis of Procedural and Distributive Fairness}

The statistics displayed in this section are reduced to the essential since a more in-depth descriptive analysis of the same variables can already be found in Borzaga and Depedri (2005), Borzaga and Tortia (2006), and Tortia (2007). These articles also present a detailed description of the characteristics of the workforce which will not be repeated here. Hence, only the average indexes of satisfaction, loyalty and fairness, as they are used in the econometric analysis, are displayed.

The number of organizations and workers included in the FIVOL-FEO survey (for more details on this survey, see Borzaga 2000; Depedri 2003) is shown in Table 6.1. Nonprofits as a whole represent about $70 \%$ of the organizations and $60 \%$ of workers. Among nonprofits, social cooperatives are the most distinct typology, representing almost one third of the whole sample of organizations and almost $30 \%$ of workers. The public sector represents about one fourth of the nonprofits sector in terms of number of organizations and almost $30 \%$ of the workforce. For-profit firms make up $10 \%$ of the workforce.

Job satisfaction is measured using different indexes (Table 6.2). The first indicator is synthetic and corresponds to the single item in the question on job satisfaction 
Table 6.1 Organizational types and their workers

\begin{tabular}{llllll}
\hline & \multicolumn{2}{c}{ Organizations } & & \multicolumn{2}{c}{ Workers } \\
\cline { 2 - 3 } \cline { 6 - 6 } & $\mathrm{N}$ & $\%$ & & $\mathrm{~N}$ & $\%$ \\
\hline Public ownership & 54 & 23.7 & & 616 & 29.8 \\
For-profit & 17 & 7.5 & & 204 & 9.9 \\
Social cooperatives & 74 & 32.5 & & 588 & 28,5 \\
Other non-religious nonprofits & 51 & 22.4 & & 440 & 21.3 \\
Religious nonprofits & 32 & 14.0 & & 218 & 10.5 \\
Total & 228 & 100 & & 2,066 & 100 \\
\hline
\end{tabular}

Table 6.2 Job satisfaction, loyalty and effort

\begin{tabular}{lllllll}
\hline & $\begin{array}{l}\text { Social } \\
\text { cooperatives }\end{array}$ & $\begin{array}{l}\text { Other non-religious } \\
\text { nonprofits }\end{array}$ & $\begin{array}{l}\text { Religious } \\
\text { nonprofits }\end{array}$ & $\begin{array}{l}\text { Public } \\
\text { ownership }\end{array}$ & $\begin{array}{l}\text { For-profit } \\
\text { firms }\end{array}$ & Total \\
\hline $\begin{array}{c}\text { Job satisfaction } \\
\quad \text { (general) }\end{array}$ & 5.38 & 5.25 & 5.25 & 4.99 & 5.38 & 5.27 \\
$\begin{array}{c}\text { Job satisfaction } \\
\quad \text { (average) }\end{array}$ & 4.66 & 4.50 & 4.86 & 4.19 & 4.50 & 4.50 \\
$\begin{array}{c}\text { Material } \\
\quad \text { satisfaction }\end{array}$ & 4.10 & 4.06 & 4.53 & 3.74 & 4.20 & 4.06 \\
$\begin{array}{c}\text { Non-material } \\
\quad \text { satisfaction }\end{array}$ & 5.09 & 4.84 & 5.10 & 4.53 & 4.71 & 4.84 \\
$\begin{array}{l}\text { Loyalty } \\
\text { Effort }\end{array}$ & 4.05 & 3.94 & 4.21 & 3.78 & 3.93 & 3.97 \\
Hourly wage $^{\mathrm{b}}$ & 1.44 & 1.06 & 1.98 & 1.31 & 0.74 & 1.32 \\
\hline
\end{tabular}

${ }^{a}$ Values ranking from 1 (minimum) to 7 (maximum)

${ }^{\text {b}}$ The values, ranking from 1 (minimum) to 5 (maximum), represent in ascending order: leave as soon as possible; looking for a job in a different sector; looking for a job in the same sector; stay at least for some years; stay as long as possible

${ }^{c}$ Effort (or stress) is measured as the difference between contractual work-hours and effective work-hours

which asked "What is your overall satisfaction with the job?" This is followed by the general average of all the fourteen specific items enclosed in the same question, subdivided into its material and non-material components. (Tortia 2007). Material satisfaction concerns the work environment, pay, working hours, job security, previous career advancement and future career advancement. Non-material satisfaction concerns professional development, recognition of one's contribution, decision-making autonomy, variety and creativity on the job, usefulness of the job for beneficiaries, relations with superiors, relations with colleagues, and relations with volunteers. This grouping was not done exclusively on an ex ante basis, but subsequent to the results of the categorical principal component analysis (CatPCA) performed on the items of satisfaction. ${ }^{2}$

\footnotetext{
${ }^{2}$ The relational items have been moved from one component to the other and considered part of non-material satisfaction even though the analysis grouped them in the material component. This ad hoc modification was suggested by the results of the econometric analysis which followed the CatPCA. The component coefficients are displayed in Table 6.4.
} 
Nonprofit organizations in general satisfy workers best, though the difference with for-profit firms is negligible. The scores concerning nonprofits and for-profit firms are very similar when material satisfaction is considered, while nonprofits show an advantage in terms of non-material satisfaction. Conversely, the public sector shows a disadvantage on all the components of satisfaction and the gap with the average total value is greater for the non-material than for the material component. ${ }^{3}$ This is true even though the public sector exhibits the highest wage level, while social cooperatives and religious nonprofits show a conspicuous disadvantage in terms of monetary incentives. Loyalty is represented by workers' willingness to stay with the organization. Workers were asked how long they predicted they would stay with their organizations and the five mutually exclusive options representing the increasing strength of the linkage between the worker and the organization were ranked from 1 to $5 .{ }^{4}$ As is apparent in Table 6.2, workers in nonprofit organizations are more loyal than workers in the public sector and for-profit firms, although the data are not complete in terms of the level of turnover and the intentions of workers that had already left in the past. Effort is represented by the excess of effective work-hours in relation to contractual work-hours, which is an imperfect proxy for effort whose meaning is nearer to stress on-the-job than to effort itself, but it is the only one available in this dataset. ${ }^{5}$

When fairness is taken into consideration (Table 6.3), it is immediately apparent that nonprofit organizations in general show a significant advantage on almost all dimensions, which are sorted into distributive and procedural aspects. Distributive fairness refers exclusively to individual and non-relational dimensions, hence to the equity of the wage in relation to the level of job responsibility, training, experience, effort, stress and the organization's ability to pay. It is does not, therefore, refer to a comparison of wages with those of other workers and managers. Religious nonprofits score highest on almost all dimensions, the low level of wages notwithstanding, and this can testify to a better ability to accommodate and satisfy the distributive expectation of a workforce that shows a relatively low level of education. ${ }^{6}$ It should also be noted, however, that workers in social cooperatives recognize more than all the others the equity of distribution when the organization's ability to pay is considered. The more inclusive organizational models allow workers to be aware of the financial limitations of their firm and this may be one

\footnotetext{
${ }^{3}$ The public sector obtains relatively high scores for some items in the material component, like professional growth and job security.

${ }^{4}$ The five mutually excluding options are "stay as long as possible", "stay at least for some years", "look for a job in the same sector", "look for a job in a different sector", "leave as soon as possible".

${ }^{5}$ The tension in the meaning of the proxy for effort is highlighted in the econometric analysis where it is clear that effort measured as excess work-hours has contrasting effects in different organizational forms.

${ }^{6}$ Religious nonprofits show the lowest percentage among all the five organizational forms in terms of workers that accomplished a university degree or a secondary school diploma (Borzaga and Tortia 2006).
} 
Table 6.3 Distributive and procedural fairness (average scores) ${ }^{\mathrm{a}}$

\begin{tabular}{|c|c|c|c|c|c|c|}
\hline & $\begin{array}{l}\text { Social } \\
\text { cooperatives }\end{array}$ & $\begin{array}{l}\text { Other non-religious } \\
\text { nonprofits }\end{array}$ & $\begin{array}{l}\text { Religious } \\
\text { nonprofits }\end{array}$ & $\begin{array}{l}\text { Public } \\
\text { ownership }\end{array}$ & For-profit & Total \\
\hline \multicolumn{7}{|l|}{ Distributive fairness } \\
\hline Responsibility & 4.0 & 4.2 & 4.6 & 3.6 & 3.9 & 4.0 \\
\hline Training & 4.1 & 4.2 & 4.4 & 3.6 & 3.8 & 4.0 \\
\hline Experience & 4.1 & 4.1 & 4.3 & 3.6 & 4.0 & 4.0 \\
\hline Effort & 4.0 & 4.0 & 4.3 & 3.4 & 3.7 & 3.8 \\
\hline $\begin{array}{l}\text { Quality of the } \\
\text { work }\end{array}$ & 4.0 & 4.0 & 4.5 & 3.5 & 3.8 & 3.9 \\
\hline Stress and tension & 3.6 & 3.6 & 3.8 & 3.0 & 3.3 & 3.4 \\
\hline $\begin{array}{l}\text { Economic } \\
\quad \text { resources of the } \\
\quad \text { organization }\end{array}$ & 5.0 & 4.4 & 4.5 & 3.5 & 3.7 & 4.2 \\
\hline Average score & 4.11 & 4.07 & 4.30 & 3.46 & 3.74 & 3.90 \\
\hline \multicolumn{7}{|l|}{ Procedural fairness } \\
\hline $\begin{array}{l}\text { Incentives to } \\
\text { contribution } \\
\text { balance }\end{array}$ & 3.5 & 3.0 & 3.3 & 2.5 & 3.3 & 3.1 \\
\hline Communication & 5.0 & 4.2 & 4.8 & 3.9 & 5.0 & 4.5 \\
\hline Being listened to & 4.7 & 4.1 & 4.4 & 3.3 & 4.2 & 4.1 \\
\hline $\begin{array}{l}\text { Professional } \\
\text { growth and } \\
\text { career }\end{array}$ & 4.0 & 3.2 & 3.2 & 2.2 & 3.0 & 3.1 \\
\hline $\begin{array}{l}\text { Growth of } \\
\text { skills and } \\
\text { capabilities }\end{array}$ & 4.7 & 4.2 & 4.5 & 3.3 & 3.9 & 4.1 \\
\hline $\begin{array}{c}\text { Transparency of } \\
\text { promotions }\end{array}$ & 3.6 & 3.0 & 3.2 & 2.1 & 3.0 & 3.0 \\
\hline Average score & 4.25 & 3.62 & 3.90 & 2.88 & 3.73 & 3.65 \\
\hline
\end{tabular}

aalues ranking from 1 (minimum) to 7 (maximum)

reason why they are willing to accept such a low wage level. Public organizations obtain the lowest scores on all dimensions, while for-profit firms remain in-between nonprofit and public ownership.

Procedural fairness is intended to express workers' judgements concerning some of the main organizational routines dealing with communication, being listened to, career advancement, development of skills and capabilities, and transparency of promotions. A first general result is that average scores are lower than in the case of distributive fairness and in the case of job satisfaction. This may indicate an increased difficulty for organizations to accomplish satisfactory results when procedures and not exclusively outcomes are considered (Benz and Stutzer 2003; Benz et al. 2004; Benz 2005). On the other hand, there is a clear need for proper institutional tools to manage the relation between workers and the organization, since some organizational forms perform better than others. 
Social cooperatives are able to respect workers' rights and to fulfil their expectations as to how industrial relations should be properly managed and human resources dealt with. When this result is seen in the light of our econometric estimates which, as will be seen, show that procedural fairness is the most significant determinant of workers' well-being in terms of job satisfaction and willingness to stay with the organization, it becomes clear that social cooperatives represent a new and interesting system of industrial relations that is less centred around monetary incentives, and more around democratic management, inclusiveness, and fair procedures.

Beside social cooperatives, all the other organizational forms can be divided into private and public. Traditional nonprofit organizations (associations and foundations) and for-profit firms receive similar evaluations, while the public sector appears to undergo serious shortcomings, mainly as far as professional growth and career, transparency of promotions and the balance of incentives to contributions are concerned. Indeed, the transparency of promotions is the only item that receives an evaluation below the median score in all organizational forms and can be considered the most critical procedural aspect in the management of the firm. The strongly relational nature of this aspect of procedural fairness (i.e. the fairness of one's promotion is evaluated in relation to the fairness of the promotion of other workers) highlights the intrinsic difficulty to build up proper routines that do not violate workers' expectations. This is well-known to scholars of labour relations (Lazear 1995). However, the weak improvements observed when switching from one ownership form to the other indicate that institutional change and evolution does play a role in the growth of the acceptance of managerial decisions concerning career advancement (Table 6.4).

Table 6.4 Grouping the items of satisfaction (categorical principal components analysis)

\begin{tabular}{llll}
\hline & 1 & 2 & 3 \\
\cline { 2 - 4 } & $\begin{array}{l}\text { Relational and } \\
\text { extrinsic component }\end{array}$ & $\begin{array}{l}\text { Intrinsic } \\
\text { component }\end{array}$ & $\begin{array}{l}\text { Economic } \\
\text { component }\end{array}$ \\
\hline $\begin{array}{l}\text { Professional development } \\
\text { Decision-making autonomy }\end{array}$ & & 0.664 & \\
$\begin{array}{l}\text { Recognition of one's contribution } \\
\text { Variety and creativity of the job }\end{array}$ & & 0.712 & \\
$\begin{array}{l}\text { Working environment } \\
\text { Social usefulness of the job }\end{array}$ & 0.568 & 0.688 & \\
Salary & 0.485 & 0.713 & \\
Working hours & 0.636 & 0.486 & 0.494 \\
Previous career advancements & & & 0.842 \\
Future career advancements & 0.694 & & \\
Job security & 0.639 & & \\
Relations with superiors & 0.647 & & \\
Relations with colleagues & & & \\
\hline
\end{tabular}

Rotation Method: Varimax with Kaiser Normalization. Rotation converged in 5 iterations 


\subsection{The Influence of Procedural and Distributive Fairness on Worker Well-Being}

The econometric analysis can shed new light on the influence of workers' fairness concerns and other personal and organizational variables of on-the job well-being both in terms of satisfaction with the job and in terms of loyalty. While the same analysis concerning the whole sample of firms can be found in Tortia (2007), here are presented the comparative results concerning the five different organizational forms. Public organizations, non-religious nonprofits and social cooperatives are introduced explicitly, together with the total of traditional nonprofits. ${ }^{7}$ The analysis is supposed to bring out statistical correlations more than causal relations since the study is carried out in a cross-section environment.

Starting with satisfaction, three sets of linear regressions were run taking as dependent variables average, material and non-material satisfaction, as shown in Tables 6.5-6.6. Average satisfaction in general is strongly influenced by fairness concerns mainly of a procedural kind (see Table 6.5). This is true in all organizational forms, and the same results will be found also in the case of material and non-material satisfaction, and of loyalty. In non-religious nonprofit organizations an increase from low to high (from 1 to 7 ) of procedural fairness corresponds on average to an increase of 2.75 points in satisfaction (which is also measured on the 1-7 Lickert scale), while the same measure is equal to 1.05 for distributive fairness. This variation equals about $60 \%$ of the average value of satisfaction, which is 4.5 . While the direct comparison of the coefficients across organizational forms is problematic given the different dimension of the samples, it is possible to compare the impact of procedural vs. distributive fairness. The former shows a much stronger influence than the latter, since the coefficient is almost three times as great for most organizational forms. The only exception is represented by social cooperatives that show a ratio slightly higher than two. We found that social cooperatives show the highest degree of procedural fairness. Hence the evidence may support the idea that the variation corresponds to decreasing marginal variations of well-being since its impact appears stronger in the contexts where workers' judgments are less favourable. On the other hand, the influence of distributive fairness does not vary significantly across organizational forms, hence its relation with worker satisfaction is more likely to be linear.

As for the other covariates, there is fairly strong evidence that women are more satisfied than men, but only in traditional nonprofits, both religious and nonreligious, while the effect is absent in social cooperatives and the public sector.

\footnotetext{
${ }^{7}$ The total of traditional nonprofits is the sum of religious and non-religious nonprofits. The explicit analysis of religious nonprofits and for-profit firms was excluded since the low number of cases (235 in the case of religious nonprofits and 180 in the case of for-profit firms) does not yield clear results beyond the influence of fairness concerns, which is common with all the other organizational forms.
} 
Table 6.5 Average satisfaction (OLS)

\begin{tabular}{lcccc}
\hline & Public & $\begin{array}{l}\text { Non-religious } \\
\text { nonprofits }\end{array}$ & All nonprofits & Social Cooperatives \\
\hline Gender & 0.078 & $0.195^{* *}$ & $0.141^{* *}$ & 0.081 \\
& 0.094 & 0.077 & 0.070 & 0.068 \\
Age (years) & $0.010^{* *}$ & 0.001 & 0.002 & 0.005 \\
& 0.004 & 0.004 & 0.003 & 0.004 \\
High school diploma & -0.027 & 0.052 & 0.031 & $0.180^{* *}$ \\
& 0.087 & 0.102 & 0.077 & 0.074 \\
University degree & -0.138 & -0.033 & -0.057 & $0.214^{* *}$ \\
& 0.125 & 0.115 & 0.093 & 0.096 \\
Specific training & $-0.195^{* *}$ & 0.100 & 0.000 & $-0.259^{* *}$ \\
& 0.091 & 0.080 & 0.073 & 0.072 \\
Open-ended contract & -0.072 & 0.088 & 0.103 & 0.106 \\
& 0.076 & 0.080 & 0.071 & 0.068 \\
Log Size & $-0.147^{* *}$ & -0.022 & -0.029 & $-0.048^{* *}$ \\
& 0.036 & 0.027 & 0.026 & 0.024 \\
Effort & -0.015 & $-0.027^{* *}$ & $-0.016^{* *}$ & $0.014^{* *}$ \\
& 0.009 & 0.007 & 0.005 & 0.007 \\
Hourly wage & 0.037 & 0.013 & 0.006 & 0.004 \\
& 0.022 & 0.016 & 0.017 & 0.015 \\
Distributive fairness & $0.157^{* *}$ & $0.174^{* *}$ & $0.163^{* *}$ & $0.169^{* *}$ \\
& 0.024 & 0.029 & 0.024 & 0.025 \\
Procedural fairness & $0.421^{* *}$ & $0.458^{* *}$ & $0.427^{* *}$ & $0.350^{* *}$ \\
& 0.027 & 0.032 & 0.025 & 0.026 \\
Constant & $2.724^{* *}$ & $1.481^{* *}$ & $1.962^{* *}$ & $2.417^{* *}$ \\
& 0.353 & 0.311 & 0.284 & 0.264 \\
$\mathrm{~N}$ & 582 & 378 & 611 & 580 \\
$\mathrm{R}^{2}$ & 0.508 & 0.606 & 0.544 & 0.499 \\
\hline
\end{tabular}

Note: Regression coefficients in plain text, standard deviations in italics. The symbol $* *$ denotes coefficients significant at the $5 \%$ level. Size of the organization is proxied by the number of employees. Effort is proxied by the number of extra hours worked

The gender effect seems to be linked to the material component of satisfaction (Table 6.6), averaging about $7 \%$ of the total in non-religious nonprofits (the mean value of satisfaction in these organizations is about 4.2) and is likely to be due to better employment possibilities and flexible labour hours for women in nonprofit organizations. Age is positively related with satisfaction only in the public sector. The public sector and social cooperatives are characterized by a negative impact of specific training. Its justification is to be found in nonmaterial satisfaction more than in the material component (Table 6.7). Hence, the frustration of the expectations of specifically trained workers is likely to be due to a lack of autonomy and creativity in the tasks that they are asked to perform, more than to a lack of monetary incentives, though this second effect is also seen in the public sector. Effort in terms of extra hours worked has a negative effect only in traditional nonprofit organizations (both religious and nonreligious).

A clearly distinctive model of industrial relations can be found at work in social cooperatives, the only organizational typology where higher education increases 
Table 6.6 Material satisfaction (OLS)

\begin{tabular}{lcccc}
\hline & & Non-religious & & \\
& Public & nonprofits & All nonprofits & Social Cooperatives \\
\hline Gender & 0.098 & $0.289^{* *}$ & $0.202^{* *}$ & 0.074 \\
& 0.110 & 0.100 & 0.090 & 0.089 \\
Age (years) & 0.006 & 0.001 & -0.002 & -0.003 \\
& 0.005 & 0.005 & 0.004 & 0.005 \\
High school diploma & -0.184 & -0.148 & -0.112 & -0.049 \\
& 0.101 & 0.133 & 0.100 & 0.097 \\
University degree & $-0.397^{* *}$ & -0.227 & $-0.290^{* *}$ & -0.044 \\
& 0.145 & 0.150 & 0.121 & 0.126 \\
Specific training & $-0.057^{* *}$ & $0.208^{* *}$ & 0.037 & -0.138 \\
& 0.106 & 0.104 & 0.094 & 0.095 \\
Open-ended contract & $0.265^{* *}$ & 0.192 & $0.329^{* *}$ & $0.339^{* *}$ \\
& 0.089 & 0.104 & 0.093 & 0.089 \\
Log Size & $-0.142^{* *}$ & 0.004 & -0.011 & -0.043 \\
& 0.042 & 0.035 & 0.033 & 0.031 \\
Effort & $-0.037^{* *}$ & $-0.040^{* *}$ & $-0.025^{* *}$ & 0.004 \\
& 0.010 & 0.009 & 0.007 & 0.010 \\
Hourly wage & $0.066^{* *}$ & 0.030 & 0.017 & 0.014 \\
& 0.025 & 0.021 & 0.022 & 0.020 \\
Distributive fairness & $0.224^{* *}$ & $0.236^{* *}$ & $0.205^{* *}$ & $0.224^{* *}$ \\
& 0.028 & 0.038 & 0.031 & 0.033 \\
Procedural fairness & $0.349^{* *}$ & $0.461^{* *}$ & $0.451^{* *}$ & $0.372^{* *}$ \\
& 0.032 & 0.041 & 0.822 & 0.034 \\
Constant & $1.526^{* *}$ & 0.274 & $0.822^{* *}$ & $1.205^{* *}$ \\
& 0.411 & 0.403 & 0.368 & 0.347 \\
$\mathrm{~N}$ & 582 & 378 & 611 & 580 \\
$\mathrm{R}^{2}$ & 0.446 & 0.532 & 0.479 & 0.423 \\
\hline
\end{tabular}

Note: see note to Table 6.5

satisfaction even though only in its non-material component. The effect is also quantitatively non-negligible, since the accomplishment of a university degree increases general satisfaction by $4 \%$ (the mean for social cooperatives is 5.2) and its non-material component by $8 \%$ on average (the mean is 4.7 ). The same result is found in the case of extra hours worked, which is positively connected with non-material satisfaction with work. Here it is possible to hypothesize a mechanism of inverse causation: higher non-material satisfaction is likely to induce workers to work overtime. The picture concerning social cooperatives is completed by the negative impact of specific training and dimension. The former, as already stated, is linked to the non-material component of satisfaction, which is decreases by about $7 \%$ on average. The interpretation of this effect may not be free of controversy. Many workers in social cooperatives would rather work in the public sector given the higher wage and job security, and this is all the more true when they are specifically trained, since this is often a precondition to being employed in the public sector. This does not seem to be the correct explanation, however, since the impact concerns only non-material satisfaction. A second possible explanation 
Table 6.7 Non-material satisfaction (OLS)

\begin{tabular}{lcccc}
\hline & Public & $\begin{array}{l}\text { Non-religious } \\
\text { nonprofits }\end{array}$ & All nonprofits & Social Cooperatives \\
\hline Gender & 0.051 & 0.127 & 0.094 & 0.047 \\
& 0.114 & 0.087 & 0.078 & 0.077 \\
Age (years) & $0.012^{* *}$ & 0.002 & 0.005 & $0.009^{* *}$ \\
& 0.005 & 0.004 & 0.004 & 0.004 \\
High school diploma & 0.094 & $0.240^{* *}$ & $0.165^{* *}$ & $0.387^{* *}$ \\
& 0.105 & 0.115 & 0.086 & 0.084 \\
University degree & 0.032 & 0.149 & 0.139 & $0.416^{* *}$ \\
& 0.151 & 0.129 & 0.105 & 0.108 \\
Specific training & $-0.282^{* *}$ & 0.009 & -0.037 & $-0.358^{* *}$ \\
& 0.110 & 0.090 & 0.081 & 0.082 \\
Open-ended contract & $-0.296^{* *}$ & 0.006 & -0.067 & -0.062 \\
& 0.092 & 0.090 & 0.080 & 0.077 \\
Log Size & $-0.153^{* *}$ & -0.030 & -0.035 & -0.050 \\
& 0.044 & 0.030 & 0.029 & 0.027 \\
Effort & 0.002 & $-0.017^{* *}$ & -0.009 & $0.021^{* *}$ \\
Hourly wage & 0.011 & 0.008 & 0.006 & 0.008 \\
& 0.019 & 0.000 & -0.004 & -0.011 \\
Distributive fairness & 0.026 & 0.019 & 0.019 & 0.017 \\
& $0.093^{* *}$ & $0.138^{* *}$ & $0.136^{* *}$ & $0.107^{* *}$ \\
Procedural fairness & 0.029 & 0.033 & 0.026 & 0.028 \\
& $0.450^{* *}$ & $0.446^{* *}$ & $0.403^{* *}$ & $0.334^{* *}$ \\
Constant & 0.033 & 0.036 & 0.028 & 0.030 \\
& $3.692^{* *}$ & $2.326^{* *}$ & $2.785^{* *}$ & $3.513^{* *}$ \\
$\mathrm{~N}$ & 0.426 & 0.349 & 0.318 & 0.298 \\
$\mathrm{R}^{2}$ & 582 & 378 & 611 & 580 \\
\hline & 0.387 & 0.496 & 0.433 & 0.382 \\
\hline
\end{tabular}

Note: see note to Table 6.5

concerning social cooperatives, which does not apply to the public sector, refers to the relatively low percentage of specifically trained workers who find it more difficult to interact with unskilled workers and reach the expected degree of self-fulfilment. This is one of the few limitations found in the organizational model characterizing social cooperatives and may indicate the need to better define a role for specialized workers, though this objective may be difficult to achieve given the higher degree of participation in decision-making and inclusion of the unskilled. Finally, the negative impact of dimension is non-linear given the use of the log of dimension as covariate. It means that small cooperatives show a higher degree of satisfaction, while the negative relation disappears as dimension grows.

The distinctive effects of social cooperatives give rise to positive relations in most cases and seem to correspond to a model of "community enterprise" (Borzaga and Tortia 2007a, b) in which the small dimension is combined with a good set of non-monetary incentives, such as better on-the-job relations based on trust, procedural fairness, and a strong motivational content linked to local embeddedness (Granovetter 1985). The peculiar incentive mix is able to foster happiness even for educated workers and in the presence of weak monetary incentives. 
When the material component of satisfaction is considered in isolation (Table 6.6), over and above the effects already underlined in previous paragraphs, a negative impact of higher education is detected in the public sector and in traditional nonprofits. The effect is strong in public organizations since it reaches $11 \%$ when measured against the average value of material satisfaction (which is 3.6), whereas it equals approximately $7 \%$ in nonprofits. Specific training shows a weak negative impact in the public sector, while it has a significant positive impact (about 5\%) in non-religious nonprofits, which are the only organizational form where this positive impact emerges. Hence, they are likely to represent the work environment most suited to accommodating the aspirations of workers with a specific professional background. A long-term contractual relation with the firm shows a general positive impact on material satisfaction, and this is quite a reasonable result since long-term relations usually imply more job security, higher wages and faster career progression. While the size of the organization reduces material satisfaction only in the public sector, a weak but widespread negative impact of extra hours worked is recorded in all organizational forms with the exception of social cooperatives where, conversely, extra hours worked show a positive impact on non-material satisfaction. Wage increases material satisfaction only in the public sector, though on average the effect is lower than $2 \%$. This result may support the idea that the organizational model in the public sector is more centred around monetary and extrinsic incentives which, given the very low degree of procedural fairness, are likely to represent an unsuccessful substitute for more transparent and equitable procedures and outcomes. Finally, it is worth emphasizing that the dimension of the impact of distributive fairness is generally higher for the material component of satisfaction than for the non-material one, though procedural fairness is still more important even in the case of material satisfaction. This result is intuitively sound since distributive fairness refers specifically to pay issues and has linkages with non-material satisfaction only insofar as professional development and the recognition of one's contribution are concerned.

The influence of procedural fairness is dominant on non-material satisfaction, while in this case the linkage with distributive fairness is much weaker. An increase from low to high in procedural fairness increases non-material satisfaction by 2.7 points in publicly-owned organizations. This, again, confirms the non-linear relation between procedural fairness and worker well-being. On the contrary, the effect of the same increase in distributive fairness is only equal to 0.6 on average. The other specific effects concerning non-material satisfaction (Table 6.7) are found in a positive impact of age in the public sector and in social cooperatives, while no effect is found in nonprofits in general. A high school diploma increases satisfaction in both nonprofits and social cooperatives. Hence, it emerges that education in general is conducive to higher non-material satisfaction, but is detrimental to satisfaction in terms of wage, job security and career advancement. This ambivalent effect is generalized and concerns all organizational forms except social cooperatives. Jobs in social services seem to satisfy educated workers, but not in relation to material incentives. The latter effect can be cast in terms of comparison income related to reference groups outside the organization and the social service sector, or be due to the insufficient purchasing power of the salary in comparison with the cost of living in general. More recent data 
concerning social cooperatives in 2005 (see the Special Issue of Impresa Sociale 2007 No. 3) strongly support these possibilities since the appropriateness of the wage in relation to the cost of living turns out to be quite low in social cooperatives and represents one of the main factors detrimental to worker well-being. ${ }^{8}$ Long-term contractual relations damage non-material satisfaction only in the public sector. This finding represents a new critical aspect concerning the public sector and can be explained in terms of deterioration of workers' intrinsic, procedural and relational motivations in this context. It appears to be particularly serious since the stability of employment is one of the hallmarks of the Italian public sector. The size of the organization is detrimental to non-material satisfaction, probably due to the more formal and impersonal relations, and to more standardized procedures in larger organizations. This effect is statistically significant only in the public sector, however. Finally, the negative impact of extra hours worked is confirmed only in non-religious nonprofits.

Overall, it can be said that various critical elements emerge in the public sector while, at the other extreme, social cooperatives seem characterized by a virtuous circle. Traditional nonprofit organizations do not present markedly positive or negative features. However, they represent the only organizational model able to valorize specific training in terms of monetary remuneration and career advancement.

Worker well-being can also be measured indirectly on the basis of the intention to stay with the organization which can be interpreted in terms of loyalty. Willingness to stay can be considered a proxy for worker well-being, since it can be presumed that workers dissatisfied with their contractual relation tend more often to be willing to quit either as soon as possible or in a reasonable span of time. ${ }^{9}$ However, it is not obvious that the determinants of loyalty are the same as the determinants of satisfaction. Indeed, a worker may prefer to quit even though s/he enjoys her/his contractual relation, for example because $s /$ he has more than one outside option or because pay is too low. Vice versa, s/he may be willing to stay even though s/he is not satisfied because s/he does not have other opportunities or because of higher monetary incentives. If happiness and loyalty do not exactly overlap, there may be a shift in the determinants, and it will be seen that this is indeed the case. A limitation of the analysis is that there is an obvious process of self-selection of more loyal workers since workers not willing to stay are more likely to have already quit. ${ }^{10}$ This is confirmed by the positive effect of age as a determinant of loyalty in all organizational forms and by the significance of being on open-end contract, which at any rate is high only in nonprofit organizations (Table 6.8). ${ }^{11}$ This may be due, on

\footnotetext{
${ }^{8}$ Indeed, it is likely to have a relevant impact on worker well-being in all sectors of the economy.

${ }^{9}$ When they are willing to quit when a new job opportunity comes, the desire to stay in the same sector means that there are elements of dissatisfaction with the specific organization in which they work. If instead they want to change sector of activity, dissatisfaction with some aspects of the job presumably concerns the sector as a whole.

${ }^{10}$ Unluckily, the measurement of turnover cannot be ascertained as control variable in this database.

${ }^{11} \mathrm{~A}$ second limitation of the analysis is that regional rates of unemployment are lacking, and they may have had an impact on loyalty since they represent a negative index of the availability of outside options.
} 
Table 6.8 Loyalty (ordered logit)

\begin{tabular}{lllll}
\hline & & $\begin{array}{l}\text { Non-religious } \\
\text { nonprofits }\end{array}$ & All nonprofits & Social Cooperatives \\
\hline Gender & 1.118 & 1.189 & 1.167 & 1.039 \\
& 0.245 & 0.279 & 0.230 & 0.197 \\
Age (years) & $1.031^{* *}$ & $1.048^{* *}$ & $1.053^{* *}$ & $1.023^{* *}$ \\
& 0.010 & 0.013 & 0.010 & 0.011 \\
High school diploma & 0.748 & 0.669 & 0.769 & $0.591^{* *}$ \\
& 0.161 & 0.212 & 0.169 & 0.128 \\
University degree & $0.458^{* *}$ & 0.671 & 0.870 & $0.564^{* *}$ \\
Specific training & 0.133 & 0.238 & 0.228 & 0.160 \\
& 1.286 & 1.061 & 0.950 & $0.631^{* *}$ \\
Open-ended contract & 0.275 & 0.250 & 0.188 & 0.125 \\
& 0.703 & $1.929^{* *}$ & $1.811^{* *}$ & 0.763 \\
Log Size. & 0.130 & 0.441 & 0.348 & 0.146 \\
Effort & 0.860 & 1.001 & 1.034 & $0.847^{* *}$ \\
Hourly wage & 0.072 & 0.077 & 0.072 & 0.054 \\
& $0.954^{* *}$ & 0.990 & 1.000 & 1.022 \\
Distributive fairness & 0.020 & 0.018 & 0.014 & 0.021 \\
& 0.958 & 0.926 & $0.910^{* *}$ & 1.066 \\
Procedural fairness & 0.044 & 0.042 & 0.041 & 0.073 \\
& $1.338^{* *}$ & $1.229 * *$ & $1.237^{* *}$ & $1.249^{* *}$ \\
N & 0.079 & 0.108 & 0.083 & 0.089 \\
Pseudo-R & 1.130 & $1.502^{* *}$ & $1.543^{* *}$ & $1.586^{* *}$ \\
\hline & 0.074 & 0.148 & 0.115 & 0.120 \\
\hline
\end{tabular}

Note: odds ratios in plain text, standard deviations in italics. The symbol $* *$ denotes odds ratios significant at the $5 \%$ level. Otherwise see note to Table 6.5

the one hand, to the tendency of many workers in social cooperatives to be willing to quit even though they are on open-end contract in order to get a better-paid job in the public sector, and, on the other hand, to a general tendency of workers in the public sector not to have a strong attachment to their job. ${ }^{12}$

Education has a strong negative impact on loyalty in social cooperatives, despite their workers demonstrating one of the highest levels of education. ${ }^{13}$ Having a university degree increases the odds of being more willing to quit by a factor of about 1.8 , while the effect is just slightly weaker in the case of a high school diploma. The former effect is still stronger in public organizations which show a level of education below social cooperatives, since the same factor is equal to 2.2. The reasons why graduate workers may be so willing to quit is likely to be different in social cooperatives and the public sector. In the former case, it is clear that young and educated workers enjoy more job opportunities and may prefer to look for more

\footnotetext{
${ }^{12}$ This evidence is shown in Borzaga and Depedri (2005) and Borzaga and Tortia (2006).

${ }^{13}$ See Borzaga and Tortia (2006).
} 
remunerative work. In the latter case, graduate workers may not be satisfied with the job and its remuneration, but often they would rather stay in the public sector by switching to a different activity. Specific training is conducive to unwillingness to stay only in social cooperatives and this again may be due to either a general tendency of workers in cooperatives to look for a better-remunerated job in the public sector, or to the inability of social cooperatives to valorize a specific professional background. The size of the organization has a negative impact on social cooperatives and this confirms the result found in the case of satisfaction. Finally, the negative influence of effort is very weak but still statistically significant in the public sector and wage has a negative impact on loyalty in traditional nonprofits. This last effect is linked to the answers given by workers in religious nonprofits and most likely refers to the difficulty of finding a different job for workers on low income ladders.

Distributive and procedural fairness again have a positive impact on loyalty, but this time the relative weight of the effect is different since distributive fairness weighs almost as much as procedural fairness in influencing the willingness to stay. The odds ratios of being more willing to stay are increased by a factor similar for both indexes of fairness in all ownership forms, though the effect of procedural fairness is still slightly stronger in nonprofits and cooperatives, while in the public sector only the effect of distributive fairness is statistically significant. In the public sector procedural fairness is extremely relevant in influencing satisfaction, mainly in its non-material component, while it does not have a relevant impact on loyalty. Indeed, in the public sector procedures are felt to be particularly unfair, causing dissatisfaction, but when it comes to loyalty only outcomes are relevant; this confirms that workers in the public sector show outcome-oriented preferences which induce them to switch to other jobs when they are not satisfied with their wage, even though the unfairness of procedures reduces their on-the-job well-being too.

It is also interesting to examine in greater depth the picture emerging from the analysis of social cooperatives. While this organizational model appeared the strongest when satisfaction, especially in its non-material component, was considered, it shows various weaknesses when the determinants of loyalty are analyzed. The most serious worries emerge from the apparent difficulty of social cooperatives to retain educated workers, probably due, in many cases, to low job security and wages. However, these negative results concerning loyalty seem to be linked also to the young age of the organizational model at the time of the research, since the new data gathered on social cooperatives in 2006 show a markedly higher degree of willingness to stay also by educated workers (Depedri 2007). Hence, the development of this model from its early stages at the beginning of the 1990s seems to be leading to more structured and effective solutions, since in many cooperatives employment relations have only reached stability over the last decade.

The overall results concerning loyalty seem to clearly point out that outcomes are more important with regard to willingness to stay than to satisfaction as already stated in previous works (Tortia 2007). Workers are satisfied with their job when material and non-material incentives are adequate (Borzaga and Tortia 2006), the environment is fair, and relations with colleagues and superiors are good (Borzaga and Depedri 2005). However, when considering whether quitting the organization 
is a desirable perspective, they take into consideration more seriously monetary incentives and distributive fairness (which in these data refers exclusively to the individual wage, but that may be imagined (and proved with new data available) to be relevant also in terms of wage comparison and the cost of living. Too low wages in the presence of a high cost of living may be a strong enough reason to convince many workers to quit even though they enjoy the work environment.

\subsection{Concluding Remarks}

The foregoing analysis has brought to light the crucial role that fairness concerns, largely those of a procedural nature, play in influencing worker well-being. This is true for all organizational forms which, however, differ in their ability to provide adequate levels of fairness. A clear divide emerges between the public and the private sector in general, since the former is at a disadvantage at the level of both worker well-being and perceived fairness. While for-profit firms and nonprofit organizations show similar levels of job-satisfaction, both material and non-material, religious nonprofits best guarantee distributive fairness and social cooperatives score highest when procedural fairness is considered. Given the more significant role of procedural fairness in influencing worker well-being, it would seem safe to state that social cooperatives represent an innovative and successful organizational form, at least as far as labour relations are concerned, the difficulties in retaining their more educated and skilled workforce notwithstanding. This conclusion is also justified by the virtuous circle existing between higher education, long-term contractual relations and workers' satisfaction which is generally high in its non-material component and which may induce workers to work more than required by the contract.

Essentially, the root of this success may be found in three elements. First, the democratic scheme of governance in cooperatives in general, and in worker cooperatives more specifically, guarantees more autonomy to workers and provides them with the opportunity to have their say even with regard to managerial decisions, in a manner that is absent in other organizational forms. Second, the multi-stakeholder scheme of governance guarantees a more inclusive organizational environment for all the actors involved, incorporating various external effects and contractual imperfections, namely those linked to asymmetric information. For instance, better information flows concerning the financial limitations of the organization are likely to improve the perception of distributive fairness even if wages are low. This is likely to improve relations and procedures in general, and hence labour relations. Third, the social role of the organization, which is often embedded at the local level and satisfies local needs, is closely interconnected with those personal relations forming the basis of the activity. Higher procedural fairness and well-being can also be linked to the specific vocational activity, since personal relations and local embeddedness are conducive to strengthened trust relations and more equitable procedures. By contrast, the many critical elements emerging in the perception of public sector workers seem to be linked mainly to a particularly low level of procedural fairness 
and of intrinsic and relational motivations, which are not made up by higher monetary incentives. These results can give a convincing explanation of the low efficiency levels, mainly due to higher costs, of public bodies.

Future work on these issues will need to concentrate more on the institutional factors that are more conducive to generating fairness of procedures, for example taking into account the degree and features of inclusiveness and worker participation in decision-making and in the activity of the firm. A second field of enquiry concerns the relation between perceived fairness and the presence of the organization's objectives besides the maximization of economic surpluses. Third, it would appear essential to further develop the relationships between local embeddedness, worker motivations and the quality of procedures in order to underscore a possible local and relational component in the perception of procedural fairness. Finally, what also remains unexplored is the impact of distributive and procedural fairness on the quality of the services delivered.

Acknowledgements I thank Carlo Borzaga for his precious comments. Of course, the standard disclaimer applies.

\section{References}

Bacchiega A, Borzaga C (2001) Social enterprise as an incentive structure. In: Borzaga C, Defourny J (eds) The emergence of social enterprise. Routledge, London

Bacchiega A, Borzaga C (2003) The economics of the third sector: toward a more comprehensive approach. In: Anheier HK, Ben-Ner A (eds) The study of the nonprofit enterprise. Theories and approaches. Kluwer, New York

Ben-Ner A, Putterman L (1999) Values and Institutions in economic analysis. In: Ben-Ner A, Putterman L (eds) Economics values and organization. Cambridge University Press, Cambridge UK

Benz M (2005) The Relevance of procedural utility for economics. Institute for Empirical Research in Economics University of Zurich, Working Paper 26

Benz M, Stutzer A (2003) Do workers enjoy procedural utility? Applied Economics Quarterly 49:149-172

Benz M, Frey B, Stutzer A (2004) Introducing procedural utility. Journal of Institutional and Theoretical Economics 160:377-401

Borzaga C (ed) (2000) Capitale umano e qualità del lavoro nei servizi sociali. Fondazione Italiana del Volontariato, Rome

Borzaga C (2003) L'analisi economica delle organizzazioni nonprofit: teorie, limiti e possibili sviluppi. In: Borzaga $\mathrm{C}$, Musella $\mathrm{M}$ (eds) Produttività ed efficienza nelle organizzazioni nonprofit. Edizioni31, Trento

Borzaga C, Depedri S (2005) Interpersonal relations and job satisfaction: Some empirical results in social and community care services. In: Gui B, Sugden R (eds) Economics and social interaction: accounting for interpersonal relations. Cambridge University Press, Cambridge UK

Borzaga C, Mittone L (1997) The multi-stakeholders versus the nonprofit organizations. University of Trento Department of Economics Discussion Paper 7

Borzaga C, Tortia E (2006) Worker motivations, job satisfaction and loyalty in public and non-profit social services. Nonprofit and Voluntary Sector Quarterly 35:225-248

Borzaga C, Tortia E (2007a) Social economy organizations in the theory of the firm. In: Clarence E, Noya A (eds) The social economy. Building inclusive communities. OECD, Paris

Borzaga C, Tortia E (2007b) The growing social content of cooperative firms: an evolutionary interpretation. 1st CIRIEC Research Conference on the Social Economy. Victoria, Canada 
Borzaga C, Tortia E (2008) Social enterprises and local development: an evolutionary approach.

Mimeo, University of Trento, Department of Economics

Depedri S (2003) La ricerca: metodologia campione e principali risultati. In: Borzaga C, Musella

M (eds) Produttività ed efficienza nelle organizzazioni nonprofit. Edizioni31, Trento

Depedri S (2007) Livelli di soddisfazione e fedeltà dei lavoratori. Impresa Sociale 17:193-211

Granovetter M (1985) Economic action and social structure: the problem of embeddedness.

American Journal of Sociology 91:481-510

Hansmann H (1996) The ownership of enterprise. The Belknap Press of Harvard University Press, Cambridge MA

Lazear EP (1995) Personnel Economics, MIT Press, Cambridge MA

Tortia E (2007) Worker well-being and perceived fairness: survey-based findings from Italy. Journal of Socio-Economics 37:2080-2094

Weisbrod BA (1977) The voluntary nonprofit sector. Lexington Books, Lexington MA

Weisbrod BA (1988) The nonprofit economy. Harvard University Press, Cambridge MA 